\title{
Comparative, Entangled, Parallel and 'Other' Cinema Histories. Another Reflection on the Comparative Mode Within New Cinema History
}

In 2016 we published an article in Alphaville on film studies and the comparative mode. ${ }^{1}$ The piece was part of a special issue on cinema heritage in Europe, and it reflected upon the buzz around doing comparative research within New Cinema History. At that time, several large research projects focused upon comparing issues of film programming, cinemagoing experiences and other aspects related to film exhibition across cities. The issue itself was edited by scholars who were involved in the European Cinema Audiences (ECA) project (see the article by Ercole, Van de Vijver and Treveri Gennari in this issue), which was innovative not only for dealing with an impressive amount of different cities across Europe.

The international comparative project was also explorative in dealing with a series of fundamental methodological issues. Collecting data on venues, programming and cinemagoing experiences had already been a burden and a major challenge for film scholars, even if they only concentrated on one venue in one city in one week or even a single day. But when scholars started to compare their findings and 'data' across two or more venues, or in more than one city, things got much more complicated. This exercise required something what was never the strongest suit in film studies, i.e. methodological rigor. The latter refers to the strength, solidity and the logic underneath a research design. It deals with making strong agreements on nearly everything. First of all, on definitions and concepts. What is a venue, what is a film, what is a programme? Who is an exhibitor and a distributor? What does watching a film consist of and how different is it from going to a cinema, making a choice, enjoying the picture and talking during and after the show? What is the film experience? And how can we compare that in a reasonable and contextualised way?

It was clear then that comparative cinema research forces scholars to rethink most of these concepts because cultural, climatological or historical differences put pressure on our common understanding of these basic constituents of cinema culture. Making a choice for watching a film in an art deco picture palace in Amsterdam, for instance, is quite different from sitting on an open air terrace 
in the middle of a hot Mexican city where a projector throws some light on a white wall around midnight. So, doing comparative research could be an endeavour that forced us to rethink what we thought we knew best (a film, a screen, a venue, a programme, a screening, ...).

The comparative mode also forced scholars to rethink, and make clear agreements on, data collection methods and transparent unambiguous protocols for data processing, analysis and interpretation. How do we count the number of venues in a city where mobile cinema or ambulant film screenings are much more common than one where the standard practice of watching a film is sitting in a building with bricks walls? What are the questions we are going to ask people when we want to talk about their past experiences? What are the methodological agreements on the analysis of interviews? Can we just translate interviews in order to compare statements? Some of the problems when doing comparative research are so fundamental that we realise that it might be that we just didn't think through all of these issues of data collection, processing and analysis before.

So, in a nutshell: comparative research on cinema's history in two or more spatial confines was worthwhile, not only in terms of understanding differences, similarities and cultural specificities (as pointed out by Ercole, Van de Vijver and Treveri Gennari in this collection), but it also forces researchers to think more thoroughly about basic conceptual, theoretical, and methodological issues of the discipline (see the contribution by Klenotic in this special issue).

The Alphaville article was a simple attempt to deal with some of those questions. It also thought about a variety of comparative set-ups, where we looked most prominently to varieties of comparative cinema history projects in their choice of methodologies and spatial confines. We came up with four modes of comparing across methodologies and space, with the most common practice being that researchers used different cities and used different research designs and methods. Only few research projects aimed at comparing different cities or other spatial entities (neighbourhoods, countries, ...) by using similar methodologies, as was the case with the ECA project (see also articles in this collection by Porubčanská, Meers and Biltereyst and by Çam and Yüksel). At the background of this typology was a social sciences inspired idea that we could also consider revisiting existing data (see the Cinema Memory and the Digital Archive project which revisits Annette Kuhn's 1930s cinema project), or even replica studies where the same data are re-examined or re-analysed by another scholar.

We, however, didn't want to promote neither one specific mode, nor all of them. All types of comparative research are valuable, and the article just tried to reflect on a meta-methodological level 
on comparative setups within the sub-discipline as a whole. In the article we only focused upon space as a distinctive parameter. The chapter disregarded any other kind of comparative research - like those on comparative modes along time, experiences, films (see contributions by Rabin, and Fuhrmann), and so on. We can compare cinema cultures in this issue across class, gender, sexual orientation, ethnicity, taste cultures, or focus on aspects of the cinema business like comparing film distribution or film flows in two or more cities (e.g. Pafort-Overduin, Lotze, Jernudd and Van Oort on film flows in three cities). We can look at festivals and their respective affective constellations as Petrychyn framed it.

It is surprising to see many of the lines or dimensions of comparative research we mentioned - some explicitly, some just in passing - and envisioned - quite optimistically maybe - for a future agenda, here already being realised, just four years later by a range of scholars from across continents. We are thinking about shared (e.g. European port cities) or identical methodologies (see the European Cinema Audiences project); the call for research beyond the US and Europe without an exoticising gaze (rural Turkish cinema (Çam and Yüksel); Jamaica (Martens), The British West Indies (Burns); Brazil (Fuhrmann); South Africa (Maingard)); research going beyond the mere cinema-related context (e.g. tourism, ideology, imperial history in Jamaica, see Martens); or intra-national comparative research (urban and small-town exhibition, for Canada see Whitehead, see also Jernudd and Lundmark), etcetera. Other contributions in this special issue go beyond the comparative towards a multi-dimensional and multi-perspective transnational approach (see Furhmann).

New Cinema History's bandwidth when it comes to periods under study is again illustrated. Every single decade since the start of the medium is in one way or another dealt with in this issue, from the early cinema culture in Canada and the Caribbean, over the classical period in Europe and North-America and the Caribbean, via rural cinema in Turkey in the 1960 and 1970s, to the late 20th and early 21st cinemas in Europe and the US.

In some of the articles, analysing cases with different languages proves to be a real challenge, but one that can be overcome (see Ercole, Van de Vijver and Treveri Gennari). At the same time a shared language can be a stimulus for joint international comparative projects, working within a 'geolinguistic region' as John Sinclair names it. Here we can refer to the 'Cultura de la Pantalla' project, a Spanish language network doing research on cinema cultures (with shared methodologies) in cities across Mexico, Colombia, Spain and the US. ${ }^{2}$

The invitation from the editors to reflect on this special issue gives us the privileged position not only to comment on the original contributions, but also, to react on some of the constructive 
critiques authors develop towards comparative New Cinema History as we framed it. Jeff Klenotic's argument is both interesting and challenging. We truly welcome his highly critical assessment of our comparative approach and his sophisticated call for a 'splatial framework', based on the 'spirit of place'. As one of the prominent voices within New Cinema History, Klenotic stirs up a lively discussion on the possibly reductive strategic character of a certain move towards comparative research.

As film studies scholars with a background in media studies and social sciences we are very aware (and wary) of negative tendencies towards mainstreaming a discipline via methods, both in film studies and in communication studies. The countermovement within New Cinema History against this mainstreaming is lively: a focus on multi-level, multi-dimensional approaches, combining political economy inspired structural business analyses with detailed programming studies and adding the missing link of audience studies, illustrate this.

More specifically Klenotic challenges our positioning comparative research as 'an essential part of a discipline's strategy to become methodologically more mature. ${ }^{3}$ In our experience, New Cinema History has never been about designing grand strategies from above, but rather about developing tactics from below in day to day collaborative research practices. This collaborative aspect, of team members working together, and even more so teams from various cultural national contexts, still is one of the original contributions to an otherwise highly individual research field. We are definitely not saying comparative research is 'better' than individual micro histories, nor are we reducing comparison to a mechanical or big data limited approach. We do make a point about the importance of a rich variety in comparative, entangled, crossed, parallel, etcetera, histories. Microhistories then are complemented, combined, integrated.

By no means did we intend to construct a teleological 'epistemological ladder', 'framing microhistories as methodologically immature and incapable of connecting or analysing macro patterns and forces as they operate in micro places. ${ }^{4}$ We firmly believe this is exactly the strength of a New Cinema History take on micro histories: it allows for a dynamic analysis from the micro to the macro, from top down to bottom up, and back. Ercole, Van de Vijver and Treveri Gennari for instance show how a study of micro-histories (in this case, three interviews) allows for a fascinating methodologically reflective comparison. Therefore Klenotic is rightly insisting on the interaction at all scales of experience and historical analysis.' 
New Cinema History has never been about a single methodology, let alone that this methodology would build upon a 'structural heteronormativity', as Petrychyn claims in his article on queer film festivals. ${ }^{5}$ He sees the preference for big data as a major cause for the exclusion of these film festivals from the New Cinema History field, but this argument doesn't stand the test. New Cinema History has always prioritised the micro level and the bottom-up lived experience, as a crucial complement to mainstream quantified data. Marginalised groups and communities are exactly given a voice through the non-text and context oriented approach, where oral history plays a crucial role. Petrychyn rightly points to the fact that film festival studies has developed into a thriving subfield, giving voice and visibility to a wide range of specialised film festivals, and with methods and epistemologies quite similar to New Cinema History. The mutual inspiration with film festival studies is clear. Moreover, this existing interaction has resulted in fruitful exchanges (e.g. panels at NECS conferences, etcetera). The absence of queer film festival research under the discursive umbrella of New Cinema History is probably more due to academic dynamics whereby similar research clusters together, in the sphere of film festival studies. But it is definitely not the result of a hidden agenda of the very open, diverse and anti-dogmatic New Cinema History community.

The 'ephemeral' to which Petrychyn refers has an important role in New Cinema History. That is exactly one of the main reasons why historical audience research is almost never limited to 'audience demographics' or geographically inspired research is neither limited to 'movie theatres'. Both focus on lived experiences of real people, from all kinds of backgrounds, in a variety of spaces (be it in buildings, drive-ins, mobile or open air cinemas), and on lived cinema cultures as reconstructed within the circulating discourses in a society, through oral history, mental mapping and other, more contextual sources. In this context, Annette Kuhn has been and still is one of the major scholars for this approach within New Cinema History. ${ }^{6}$

If New Cinema History would really be 'inattentive to cinema institutions organised by marginalised communities' it would simply go against its own agenda. Considering pioneers within the approach such as Robert C. Allen, who from very early on focussed on black (and mixed but spatially separate) cinema-going in the rural south of the US; Kate Bowles' work on rural audiences in New South Wales (Australia), and more recently the efforts of giving a voice to unheard women voices in mid-twentieth century patriarchal societies such as urban and rural Italy, the agenda seems fully in action. ${ }^{7}$ This does not imply 'queering New Cinema History' is not a project worthwhile exploring, we 
can only welcome valuable new perspectives, as the New Cinema History community has always done. But simultaneously bashing the open and non-dogmatic principles the community is built upon seems rather uncalled for.

Both Klenotic and Petrychyn to a certain degree seem to assume that a comparative approach within New Cinema History implies big data or a quantitative data-driven research agenda. We can only emphasise the wide methodological possibilities and realities of New Cinema History as a counterargument, as the contributions in this very issue yet again demonstrate. And - not to the reader's surprise we hope - fully rejecting a 'teleological and centripetal narrative that centres New Cinema History on methods', we do insist on methodological rigor and transparency, be it comparative or otherwise, combined with an open research spirit whereby basic questions and curiosity guide the researcher towards the most adequate method, rather than leaving it opaque or, more extreme, having the method determine the questions.

To conclude these brief reflections, we confirm that comparative research is not only about studying parallel or 'other' histories (cf. Hoogland's article). This special issue strongly illustrates that comparing cinema's past becomes tremendously interesting when these pasts touched each other at the time, when they had a common ground, or when they were entangled. The histoire croisée approach is much more than a theoretical option because an internationally or even globally oriented medium like cinema has an intensively entangled history. It is entangled in terms of films, of course - film crossing from one city, country or continent to another. Cinema history was entangled in terms of people like filmmakers, stars, camera personnel, businessmen and women being active in different spatial or temporal entities. There was an intensive entanglement in terms of money, strategies, power, public diplomacy (see Fuhrmann). And it was entangled also in cinema reception with audiences consuming foreign pictures, reading non-domestic magazines, dreaming of worlds they could (probably) never (physically) reach. So, entanglement was always at the heart of cinema - in terms of business, flows, content, labour, stories and phantasies.

\section{Notes}

1 Daniel Biltereyst and Philippe Meers, "New Cinema History and the Comparative Mode: Reflections on Comparing Historical Cinema Cultures," Alphaville Journal of Film and Screen Media 11 (2016): 13-32. 
2 J. Sinclair, “Geolinguistic Region as Global Space: The Case of Latin America," in The New Communications Landscape, ed. G. Wang , J. Servaes and A. Goonasekera (London: Routledge, 2000), 19-32; Philippe Meers, Daniël Biltereyst and José Carlos Lozano, “Cultura de la Pantalla network : writing new cinema histories across Latin America and Europe," Revista Internacional de Comunicación y Desarollo 2(9) (2018): 158-165.

3 Biltereyst and Meers, "New Cinema History and the Comparative Mode," 25.

4 Jeffrey Klenotic, “Mapping Flat, Deep, and Slow: On the 'Spirit of Place' in New Cinema History,” TMG Journal for Media History 23, no. 1-2 (2020): 12, DOI: 10.18146/tmg.789.

5 Jonathan Petrychyn, "Queering New Cinema History: Affective Methodologies for Comparative Histories," TMG Journal for Media History 23, no. 1-2 (2020): 1, https://dx.doi.org/10.18146/tmg.588

6 E.g. Annette Kuhn, An Everyday Magic: Cinema and Cultural Memory (London; New York: I.B.Tauris, 2002). Annette Kuhn, “Heterotopia, Heterochronia: Place and Time in Cinema Memory,” Screen 45, no.2 (2004): 106-114. Annette Kuhn, Daniel Biltereyst and Philippe Meers, “Memories of Cinemagoing and Film Experience ... An introduction,” Memory Studies, 10, no.1 (2017): 3-16.

7 Robert C. Allen, Going to the Show project, Mapping Moviegoing in North Carolina http://gtts.oasis.unc. edu/; Kate Bowles, “Three Miles of Rough Dirt Road': Towards an Audience-Centred Approach to Cinema Studies in Australia," Studies In Australasian Cinema 1(3) (2007): 245-260; Daniela Treveri Gennari, Silvia Dibeltulo, Danielle Hipkins and Catherine O’Rawe, “Analysing Memories Through Video-Interviews: A Case Study of Post-War Italian Cinema-going,” in Routledge Companion to New Cinema History, ed. Daniël Biltereyst, Richard Maltby and Philippe Meers (London: Routledge, 2019): 344-354.

\section{Biographies}

Daniel Biltereyst is Professor in Film and Media History and director of the Cinema and Media Studies (CIMS) research centre at Ghent University, Belgium. Besides exploring new approaches to historical media and cinema cultures, he is engaged in work on screen culture as a site of censorship, controversy and public debate. He recently published in the Historical Journal of Film, Radio \& Television, Memory Studies and Film Studies. With Richard Maltby and Philippe Meers, he co-edited Explorations in New Cinema History: Approaches and Case Studies (2011), Audiences, Cinema and Modernity: New Perspectives on European Cinema History (2012) and The Routledge Companion to New Cinema History (2019). With Annette Kuhn and Philippe Meers, he co-edited a special issue of Memory Studies (2017) on memories of cinemagoing. He just published Mapping Movie Magazines (Palgrave, with L. Van de Vijver, 2020). 
Philippe Meers is Professor in Film and Media Studies at the University of Antwerp, Belgium, where he is deputy director of the Visual and Digital Cultures Research Center (ViDi). He has published widely on historical and contemporary film cultures and audiences in, e.g. Screen and Media, Culture \& Society. With Richard Maltby and Daniel Biltereyst, he co-edited Explorations in New Cinema History: Approaches and Case Studies (2011), Audiences, Cinema and Modernity: New Perspectives on European Cinema History (2012) and The Routledge Companion to New Cinema History (2019). With Annette Kuhn and Daniel Biltereyst, he co-edited a special issue of Memory Studies (2017) on memories of cinemagoing. 


\section{TMG Journal for Media History}

Volume 23 No $(1 / 2) / 2020$

\section{DOI}

https://dx.doi.org/10.18146/tmg.795

\section{PUBLISHER}

Netherlands Institute for Sound and Vision

\section{COPYRIGHT}

Each article is copyrighted (c) by its author(s) and is published under license from the author(s). When a paper is accepted for publication, authors will be requested to agree with the Creative Commons Attribution 4.0 International License. 